\title{
E-PEDAGOGIS BAGI TUTOR UNTUK MENINGKATKAN KUALITAS PEMBELAJARAN DI PUSAT KEGIATAN BELAJAR MASYARAKAT (PKBM)
}

\author{
Vidila Rosalina ${ }^{1)}$, Harsiti $^{2}$, Saleh Dwiatno ${ }^{3)}$ \\ ${ }^{1}$ Program Studi Teknik Informatika, Universitas Serang Raya, Serang Banten \\ ${ }^{2}$ Program Studi Sistem Informasi, Universitas Serang Raya, Serang Banten \\ ${ }^{3}$ Program Studi Sistem Komputer, Universitas Serang Raya, Serang Banten \\ e-mail : ' vidila.suhendarsah@gmail.com*. ${ }^{2}$ harsiti@yahoo.com, ${ }^{3}$ saleh.dwiyatno@gmail.com
}

\begin{abstract}
ABSTRAK
PKBM (Pusat Kegiatan Belajar Masyarakat) atau CLC (Community Learning Center) merupakan suatu lembaga yang dibentuk, diselenggarakan/dikelola dan dikembangkan dengan prinsip "dari", "oleh" dan "untuk" masyarakat/komunitas. Filosofi PKBM secara ringkas adalah dari, oleh dan untuk masyarakat. Ini berarti bahwa PKBM adalah suatu institusi yang berbasis masyarakat (Community Based Institution). Permasalahan yang hadapi oleh PKBM (Pusat Kegiatan Belajar Masyarakat) adalah kualitas pembelajaran yang rendah karena kompetensi tenaga pendidik (tutor) yang relatif rendah dan kurang memahami pemanfaatan TIK dan e-learning. Metode pendekatan pemecahan masalah yang digunakan dalam IbM ini adalah dengan mewujudkan konsep belajar PKBM (Pusat Kegiatan Belajar Masyarakat) berbasis TIK dengan membangun e-pedagogis dan melakukan pelatihan bagi para tutor dalam menggunakan e-learning dan virtual class untuk meningkatkan kualitas pembelajaran, meningkatkan kompetensi tutor, dan menyediakan bahan ajar dan modul bagi siswa. Luaran IbM ini berupa epedagogis bagi para tutor di PKBM (Pusat Kegiatan Belajar Masyarakat) dan kemampuan tutor dalam memanfaatkan TIK dan e-learning dalam proses belajar mengajar. Hasil IbM ini diharapkan bisa diterapkan di PKBM (Pusat Kegiatan Belajar Masyarakat) di seluruh indonesia untuk meningkatkan kualitas pembelajaran non formal agar setara dengan pendidikan formal lainnya.
\end{abstract}

Kata kunci: e-Pedagogis, IbM, PKBM, Tutor

\section{PENDAHULUAN}

\subsection{Analisis Situasi}

PKBM (Pusat Kegiatan Belajar Masyarakat) atau CLC (Community Learning Center) adalah suatu lembaga yang dibentuk, diselenggarakan/dikelola dan dikembangkan dengan prinsip "dari", "oleh" dan "untuk" masyarakat/komunitas. Filosofi PKBM secara ringkas adalah dari, oleh dan untuk masyarakat. Ini berarti bahwa PKBM adalah suatu institusi yang berbasis masyarakat (Community Based Institution) [1].

Secara internasional umumnya dikenal dengan Community Learning Center (CLC). Sedangkan di masing-masing negara di dunia memiliki sebutan atau istilah yang berbeda, seperti di Jepang disebut Kominkan, di Singapura disebut Community Club (secara nasional diorganisir oleh People Association), di Malaysia dikenal Pusat Kegiatan Masyarakat (secara nasional diorganisir oleh Jabatan Kemajuan Masyarakat (KEMAS) Kementerian Kemajuan Luar Bandar dan Wilayah), di Korea Selatan dikenal Lifelong Education Center (secara nasional diorganisir oleh 
NILE/National Institute of Lifelong Education), sedangkan di Thailand tidak ada nama khusus untuk CLC, dimana pembinaannya dilakukan oleh lembaga SICED (Sirindhorn Institute for Continuing Education and Development) di bawah ONIE (Office of Nonformal dan Informal Education) Thailand Department of Education dan lain-lainnya.

Program-program yang diselenggarakan di PKBM dapat sangat beragam dan dapat juga tak terbatas, namun harus sesuai dengan kondisi, potensi dan kebutuhan masyarakat di mana PKBM itu berada atau dikatakan yang relevan, serta program-program itu harus bermakna dan bermanfaat. Program-program tersebut umumnya antara lain :

a. Pendidikan Kesetaraan : Paket A, Paket B dan Paket C.

b. Pendidikan Anak Usia Dini (PAUD)

c. Pendidikan Keaksaraan Fungsional/KF (bagi Buta Aksara)

d. Taman Bacaan Masyarakat (TBM)

e. Pendidikan Keterampilan, Kecakapan Hidup (life skill) dan Kursus-kursus.

f. Pendidikan Kewarganegaraan, Kerumahtanggaan dan Keorangtuaan (parenting)

g. Pendidikan Mental dan Spiritual-Religius / Keagamaan

h. Pendidikan Kewirausahaan, Usaha Produktif Masyarakat, Kelompok Belajar Usaha (KBU dan KUBE)

i. Pendidikan Seni, Budaya dan Olah Raga

j. Pendidikan Lingkungan Hidup, Pelestarian Hutan, Penyuluhan Pertanian, Peternakan dan Perikanan

k. Pendidikan Kesehatan Masyarakat.

1. Dan lain-lainnya.

Penjelasan singkat jenis program di atas, sebagai berikut :

a. Pendidikan Kesetaraan Paket A adalah program pendidikan kesetaraan setingkat SD (Sekolah Dasar). Program ini ditujukan bagi yang ingin mendapatkan pendidikan setingkat SD. Paket B adalah program pendidikan kesetaraan setingkat SMP/SLTP (Sekolah Menengah/Lanjutan Tingkat Pertama). Paket $\mathrm{C}$ adalah program pendidikan kesetaraan setingkat SMA/SLTA (Sekolah Menengah/Lanjutan Tingkat Atas).

b. Pendidikan Anak Usia Dini (PAUD) ditujukan bagi anak-anak dalam rentang usia 0 - 6 tahun. Program ini dapat terdiri dari berbagai kegiatan seperti Taman Kanak-Kanak, Kelompok Bermain, Taman Penitipan Anak dan lain-lainnya. 
c. Keaksaraan Fungsional (KF) adalah pengembangan program pemberantasan buta aksara/huruf. Program ini dilaksanakan selain bertujuan untuk pemberantasan buta huruf/aksara juga diberi pelatihan agar para peserta didik (umumnya telah berusia dewasa) dapat meningkatkan keterampilan yang dimilikinya sehingga kesejahteraan hidupnya dapat lebih ditingkatkan pula.

d. Taman Bacaan Masyarakat (TBM) merupakan sarana bagi masyarakat untuk meningkatkan pengetahuan melalui membaca. TBM adalah semacam perpusatakaan yang menyediakan buku-buku bacaan yang bermanfaat dan sesuai dengan kebutuhan masyarakat.

e. Pendidikan Keterampilan (vokasional), Kecakapan Hidup (life skill) dan Kursus-kursus merupakan program yang memberikan keterampilan praktis kepada masyarakat untuk meningkatkan kualitas hidupnya seperti keterampilan pertukangan, permesinan, tata busana, komputer, jasa, dsb.

f. Pendidikan Mental dan Spiritual-Religius / Keagamaan sebenarnya program yang sudah sangat biasa atau umum diselenggarakan oleh masyarakat seperti pengajian, Majelis Takhlim, Iqro, Taman Pendidikan Al Qur'an, sekolah minggu, pemahaman Alkitab, dan lain sebagainya yang berkaitan peningkatan ke'imanan.

g. Pendidikan Kewirausahaan, Usaha Produktif Masyarakat dan Kelompok Belajar Usaha adalah program yang ditujukan untuk meningkatkan kesejahteraan masyarakat melalui usaha/bisnis masyarakat baik dilakukan secara berkelompok atau bersama-sama. Selain itu juga sebagai sumber pembiayaan bagi keberlangsungan lembaga atau program-program lainnya. Keberhasilan program ini akan makin meningkatkan semangat masyarakat untuk terus belajar dan berkembang atau dijadikan sebagai ragi belajar.

PKBM dapat dibentuk atau diselenggarakan di suatu wilayah/daerah yang umum berdasarkan wilayah seperti contoh misalnya : Rukun Tetangga (RT), Rukun Warga (RW), Kampung/Desa/Kelurahan atau Kecamatan. Namun juga dapat berdasarkan/berbasis/tematik suatu komunitas/masyarakat tertentu seperti : komunitas di daerah padat penduduk (kumuh), komunitas miskin perkotaan, komunitas anak jalanan, komunitas wanita tuna susila/ex, komunitas petani atau peternak, komunitas sekitar hutan, komunitas nelayan/pesisir dan perikanan, komunitas narapidana/ex, komunitas santri/pesantren, komunitas buruh industri, komunitas pengrajin, komunitas tenaga kerja indonesia di luar negeri, komunitas di pasar, mall, terminal, stasiun, dsb. 
Menurut Departemen Pendidikan Nasional [2] Paramater PKBM terdiri dari

a. Partisipasi masyarakat ( Community participation )

Salah satu ukuran kemajuan suatu PKBM adalah kualitas dan kuantitas partisipasi masyarakat dalam berbagai aspek kegiatan dan permasalahan PKBM tersebut. Semakin tinggi jumlah anggota masyarakat yang berpartisipasi dalam suatu PKBM maka semakin tinggi pula dianggap keberhasilan dan kemajuan PKBM tersebut. Demikian juga semakin tinggi mutu keterlibatan masyarakat setempat dalam suatu PKBM menggambarkan semakin tinggi kemajuan suatu PKBM. Semakin tinggi tingkat partisipasi masyarakat dalam suatu PKBM, akan terlihat dalam setiap proses manajemen yang ada. Baik dalam perencanaan, pengorganisasian, pelaksanaan, dan pengendalian. Partisipasi masyarakat juga dapat ditunjukkan dalam dukungan dalam penyediaan sarana dan prasarana, dana, tenaga personalia, ide dan gagasan, dan sebagainya.

b. Manfaat bagi masyarakat ( Impact)

Parameter berikutnya untuk mengukur tingkat kemajuan suatu PKBM adalah manfaat bagi masyarakat. Yang dimaksud dengan manfaat (impact) adalah seberapa besar PKBM tersebut telah memberikan sumbangan bagi peningkatan mutu kehidupan komunitas tersebut. Sumbangan ini dapat berupa peningkatan pengetahuan anggota masyarakat, peningkatan keterampilan, perbaikan perilaku, peningkatan pendapatan, penciptaan lapangan kerja, penciptaan keharmonisan, dan lain-lain.

c. Mutu dan relevansi program

Mutu dan relevansi program yang diselenggarakan oleh PKBM merupakan parameter berikutnya bagi kemajuan suatu PKBM. Untuk menilai mutu dan relevansi program yang diselenggarakan, perla memperhatikan input, proses dan output dalam pelaksanaan program. Untuk mengukur mutu dan relevansi program-program pembelajaran yang diselenggarakan telah banyak dikembangkan model-model pengukurannya.

d. Kemandirian dan keberlanjutan lembaga (Sustainability)

Yang dimaksud kemandirian disini adalah kemampuan PKBM untuk tetap berjalan dengan baik melaksanakan berbagai programnya tanpa harus bergantung kepada berbagai pihak lain di luar dirinya. Sedangkan yang dimaksud dengan keberlanjutan lembaga disini adalah kemampuan PKBM untuk tetap bertahan terus menerus melaksanakan seluruh Programnya. Untuk meningkatkan kemandirian dan keberlanjutan lembaga perlu dikembangkan sistem pendanaan yang lebih mandiri dan berkelanjutan, meningkatkan kemampuan lembaga dalam melakukan 
inovasi inovasi program, membangun sistem manajemen yang baik, melakukan pelatihan dan pengembangan personalia yang baik dan melakukan kaderisasi kepemimpinan. Inovasi program.

Berdasarkan hasil penelitian yang dilakukan di PKBM Wilayah Banten, pada umumnya para pendidik (tutor) di PKBM masih memiliki kemampuan yang rendah dalam kemampuan TIK maupun E-Learning seperti yang terlihat pada tabel 1.

Tabel 1. Data Responden Tingkat Kemampuan Tutor

\begin{tabular}{|c|l|c|c|}
\hline No & Tingkat Kemampuan & TIK & E-Learning \\
\hline 1 & Tidak Bisa & 15 & 25 \\
\hline 2 & Agak Bisa & 7 & 0 \\
\hline 3 & Bisa & 3 & 0 \\
\hline 4 & Mahir & 0 & 0 \\
\hline
\end{tabular}

Dan secara umum para pendidik (tutor) di PKBM belum pernah memanfaatkan TIK maupun $E$ Learning dalam kegiatan pembelajaran di PKBM seperti yang terlihat pada tabel 2.

Tabel 2. Data Responden Tingkat Pemanfaatan TIK dan e-learning

\begin{tabular}{|c|l|c|c|}
\hline No & Tingkat Kemampuan & TIK & E-Learning \\
\hline 1 & Tidak Pernah & 25 & 25 \\
\hline 2 & Kadang-kadang & 0 & 0 \\
\hline 3 & Pernah & 0 & 0 \\
\hline 4 & Sering & 0 & 0 \\
\hline
\end{tabular}

\subsection{Permasalahan Mitra}

PKBM (Pusat Kegiatan Belajar Masyarakat) di Indonesia atau di Banten khususnya memiliki beberapa kendala baik yang bersifat sosial maupun manajerial yang dihadapi, sehingga kualitas pembelajaran yang diharapkan kurang optimal. Beberapa kendala tersebut antara lain :

a. Kompetensi tenaga pendidik (tutor) yang relatif rendah dan kurang memahami pemanfaatan TIK, e-learning dan virtual class.

b. Jumlah modul pembelajaran yang terbatas dan belum sesuai dengan yang dibutuhkan.

c. Masih terbatasnya fasilitas penunjang kegiatan belajar-mengajar. 
d. Secara sosial masyarakat yang belajar di PKBM adalah pekerja, baik sebagai petani, buruh, nelayan, ataupun pedagang, sehingga membutuhkan waktu yang fleksibel dalam mengikuti kegiatan belajar mengajar.

Kegiatan pengabdian masyarakat IbM e-pedagogis bagi tutor untuk meningkatkan kualitas pembelajaran di PKBM yang diharapkan atau dihasilkan dari kegiatan ini adalah:

a. Diimplementasikannya e-pedagogis bagi para tutor yang dapat dipakai dalam proses pembelajaran di PKBM sehingga bisa meningkatkan kualitas pembelajaran di PKBM.

b. Meningkatnya kemampuan profesional para tutor di PKBM dalam hal: Konsep Media Pembelajaran dengan menggunakan e-learning dan virtual class, bertambahnya wawasan tentang Perkembangan Teknologi, memahami konsep Pengetahuan Teknologi Informasi dan Komunikasi.

\section{METODE PELAKSANAAN}

\subsection{Metode Penyelesaian Masalah}

Untuk mengantisipasi permasalahan yang dihadapi oleh Pusat kegiatan Belajar Masyarakat (PKBM) menggunakan dua metode pendekatan, yaitu:

Metode pertama, IbM ini akan menggunakan metode pendekatan Kaji Tindak (Action Research) .Kleiman et al. (2001) mengemukakan bahwa metode kaji tindak merupakan jenis program aksi yang dapat menghasilkan pengetahuan baru dalam rangka pemecahan masalah atau perbaikan terhadap masalah dalam kehidupan praktis .Ada dua tujuan utama dari metode ini yaitu berupa penemuan metode baru dalam pemecahan masalah secara praktis oleh tim pelaksana program, sedangkan pemilik masalah mendapatkan metode yang lebih efisien dalam pemecahan masalah secara praktis di lapangan (Burns, 1994). Dalam kaji tindak partisipatif, kerja sama antara tim pengusul dengan "pemilik masalah" (problem owner) merupakan hal penting untuk diterapkan. Ketergantungan saling menguntungkan antara tim dan pemangku masalah terletak pada pemahaman bersama terhadap masalah yang harus dipecahkan, keterampilan, pengalaman, dan kompetensi; agar proses realisasi program dan pengembangannya dapat tercapai dengan optimal. Kaji tindak partisipatif merupakan kombinasi antara penelitian (research) dengan tindakan (action) yang dilakukan secara partisipatif guna meningkatkan aspek kehidupan masyarakat . Dalam konteks IbM ini, metode kaji tindak partisipatif akan diterapkan 
Dengan membangun e-pedagogis bagi para tutor di Pusat Kegiatan Belajar masyarakat (PKBM) untuk meningkatan kegiatan belajar mengajar.

Metode kedua, adalah dengan metode peer coaching, yaitu suatu metode yang dilakukan untuk menyampaikan informasi, pesan, ide, pengetahuan yang dilakukan oleh teman sejawatnya. Dalam hal ini kami dosen Universitas Serang Raya merupakan teman sejawat bagi para tenaga pendidik (tutor) di PKBM. Tentunya ini didasari dengan pertimbangan agar kami dapat memperoleh informasi yang seluas-luasnya tentang proses belajar mengajar dan permasalahan yang ada di PKBM. Sedangkan teknik penyampaian materi adalah: ceramah, tanya jawab, diskusi, praktek, workshop, tugas, dan evaluasi.

\subsection{Tahapan Program Kegiatan}

Langkah-langkah yang dilakukan dalam kegiatan IbM ini sebagai solusi permasalahan yang terjadi di PKBM adalah:

1. Melakukan studi pendahuluan berupa kajian literatur terkait dan studi lapangan awal terkait sistem e-pedagogis yang akan dibangun di PKBM.

2. Membuat analisis dan pemodelan e-pedagogis bagi tutor di PKBM.

3. Membangun e-pedagogis untuk para tutor di PKBM.

4. Melakukan Pelatihan dan workshop bagi para tutor di PKBM, yang terdiri dari pelatihan :

a. Melakukan pelatihan mengoperasikan komputer dan teknologi TIK pada umumnya untuk kepentingan pembelajaran. Materi : Pengetahuan Teknologi Informasi dan Komunikasi bagi Tutor PKBM.

b. Melakukan pelatihan tentang e-learning bagi tenaga pendidik (tutor) PKBM Materi : $E$ Learning Dan Virtual Class Untuk Kegiatan Belajar Mengajar Di PKBM

c. Melakukan pemanfaatan e-pedagogis dalam kegiatan belajar mengajar di PKBM. Materi : e-Pedagogis dalam meningkatkan kualitas pembelajaran di PKBM

5. Melaksanakan monitoring dan evaluasi secara partisipatif agar proses program IbM ini sesuai dengan standar pelaksanaan.

Tahapan - tahapan tersebut akan dilakukan secara sistematis dan kolaboratif antara tim pengusul, PKBM-PKBM, dan Universitas Serang Raya. Sehingga setiap tahap akan selalu dievaluasi secara berkesinambungan pula. 


\section{HASIL KEGIATAN}

Jumlah relawan tutor yang mengikuti kegiatan ini sebanyak 30 orang dari mitra PKBM Permadani dan PKBM Melati.

Sebelum dan sesudah pelatihan, peserta diberikan test (pre test dan post test) dengan tujuan untuk mengetahui pengetahuan tutor terhadap materi pelatihan e-pedagogis.

Dari pertanyaan pre test yang bersifat menggali kepada semua relawan tutor tersebut, sebanyak 25 persen bisa memanfaatkan Teknologi informasi Komputer (TIK) dan 100\% belum pernah memanfaatkan e-learning dalam kegiatan belajar mengajar di PKBM (lihat tabel 1 dan tabel 2).

Dari hasil post test yang dilakukan setelah materi TIK dan e-pedagogis diberikan terjadi peningkatan pengetahuan relawan tutor sebesar 90\% dengan nilai rata-rata 92.24.

Hasil dari implemantasi e-pedagogis ini adalah tiap tutor sudah memiliki kelas virtual untuk tiap mata pelajaran yang diampu dan murid juga memiliki account untuk bisa masuk ke dalam kelas virtual tersebut untuk mendapatkan materi pelajaran secara online maupun untuk ujian online.

\section{KESIMPULAN}

a. Meningkatnya kemampuan profesional para tutor di PKBM dalam hal: Konsep Media Pembelajaran dengan menggunakan e-learning dan virtual class, bertambahnya wawasan tentang Perkembangan Teknologi, memahami konsep Pengetahuan Teknologi Informasi dan Komunikasi sebesar 90\% dengan nilai rata-rata 92.24.

b. Meningkatkan kualitas pembelajaran di PKBM setelah diimplementasikannya EDMODO sebagai e-pedagogis bagi para relawan tutor dan siswa-siswi PKBM sehingga bisa memanfaatkan virtual class, belajar online, ujian online dan siswa dapat sharing modul dan materi pembelajaran sehingga dapat mengantisipasi jumlah modul pembelajaran yang terbatas dan belum sesuai dengan yang dibutuhkan.

c. Pemanfaatan e-pedagogis ini bisa digunakan dengan menggunakan smartphone sehingga dapat mengantisipasi terbatasnya fasilitas penunjang kegiatan belajar-mengajar misalnya komputer, ruang kelas, dan waktu.

d. Secara sosial masyarakat yang belajar di PKBM adalah pekerja, baik sebagai petani, buruh, nelayan, ataupun pedagang, sehingga membutuhkan waktu yang fleksibel dalam mengikuti 
kegiatan belajar mengajar dan belajar dimana saja, semua ini hanya bisa terwujud dengan pemanfaatan e-pedagogis, e-learning dan virtual class.

\section{DAFTAR PUSTAKA}

[1] Departemen Pendidikan Nasional Direktorat Pendidik dan Tenaga Kependidikan Pendidikan Nonformal. "Konsep dan Strategi Pengembangan Pusat Kegiatan Belajar Masyarakat (PKBM)". (Jakarta, 2006), p6.

[2] Departemen Pendidikan Nasional Direktorat Pendidik dan Tenaga Kependidikan Pendidikan Nonformal.op.cit.p16-17

[3] Efendi, E. dan H, Zhuang., 2005, E-Learning Konsep dan Aplikasi, Penerit ANDI, Yogyakarta.

[4] Sanjaya, R dan Leong, M, 2008, Mudah Membangun Web E-Learning, Penerbit Universitas Atma Jaya, Yogyakarta.

[5] Renaldy, B dkk, 2008, Memasuki Dunia E-Learning (Solusi Cepat Mengembangkan Content Digital), Penerbit INFORMATIKA, Yogyakarta.

[6] Setyo, K, 2005, Membangun E-Learning Dengan MOODLE, Penerbit ANDI,Yogyakarta.

[7] Sunendiari, S, 2014, Pelatihan Penelitian Tindakan Kelas Bagi Guru-Guru SMA di Wilayah Bandung Dalam Upaya Meningkatkan kompetensi Guru, Prosiding Seminar Nasional Penelitian dan PKM: Sains, Teknologi, dan Ilmu Kesehatan, SNaPP2014, 4(1)711, Bandung.

[8] http://edmodo.com/userguide 